\title{
Mitochondrial Protein p26 BCL2 Reduces Growth Factor Requirements of NIH3T3 Fibroblasts
}

\author{
John C. Reed, ${ }^{* 1}$ Harvinder S. Talwar, $†$ Michael Cuddy, ${ }^{*}$ Gyorgy Baffy, $\ddagger$ \\ JoHN WILLIAMSON, $\ddagger$ ULF R. RAPP, § AND GARY J. FishER $\dagger$
}

University of Pennsylvania School of Medicine, *Department of Pathology and Laboratory Medicine, and $\ddagger$ Department of Biochemistry, Philadelphia, Pennsylvania 19104; §The National Cancer Institute Research Facility at Frederick, Laboratory of Viral Carcinogenesis, Frederick, Maryland 21710; and $\dagger$ University of Michigan School of Medicine, Department of Dermatology, Ann Arbor, Michigan 48109

The BCL2 (B cell lymphoma/leukemia-2) proto-oncogene encodes a $26-\mathrm{kDa}$ protein that has been localized to the inner mitochondrial membrane and that has been shown to enhance the survival of some types of hematopoietic cells. Here we show that NIH3T3 fibroblasts stably transfected with a BCL2 expression plasmid exhibit reduced dependence on competence-inducing growth factors (platelet-derived growth factor, PDGF; epidermal growth factor, EGF) for initiation of DNA synthesis. The importance of BCL2 for growth factorinduced proliferation of these cells was further confirmed by the useage of BCL2 antisense oligodeoxynucleotides. The mechanisms by which overexpression of p26 BCL2 contributes to fibroblast proliferation are unknown, but do not involve alterations in: (a) the production of inositol triphosphates $\left(\mathrm{IP}_{3}\right),(\mathrm{b})$ PDGF-induced transient elevations in cytosolic $\mathrm{Ca}^{2+}$ ions, or (c) the activity of protein kinase $\mathrm{C}$ enzymes in these transfected cells. The results imply that changes in mitochondrial functions play an important role in the early stages of the cell cycle that render $3 \mathrm{~T} 3$ cells competent to respond to the serum progression factors that stimulate entry into S-phase. (c) 1991 Academic Press, Inc.

\section{INTRODUCTION}

The B cell lymphoma/leukemia-2 (BCL2) oncogene encodes a $26-\mathrm{kDa}$ integral membrane protein that has been implicated in the earliest stages of lymphoma development in humans [1]. Though comparisons of $\mathrm{p} 26$ BCL2 with other protein sequences available in databases have provided few clues about the possible activities of this oncopeptide, recently the BCL2-encoded protein has been localized by confocal immunofluorescence microscopy and subcellular fractionation to the

\footnotetext{
${ }^{1}$ To whom correspondence and reprint requests should be addressed.
}

inner mitochondrial membrane [2]. Presumably, therefore, BCL2 regulates some aspect of mitochondrial function. Gene transfer studies have shown that overexpression of p26 BCL2 can markedly enhance the survival of some types of hematopoietic cells without concomitantly stimulating cellular growth $[2-5]$, a finding consistent with the mitochondrial location of the BCL2 protein. In fact, because of its cell survival enhancing activity, no strong evidence has yet been presented to indicate that BCL2 can regulate cell cycle entry or progression.

Investigations of the regulation of BCL2 proto-oncogene expression in normal cells are limited to human lymphocytes. In quiescent lymphocytes, BCL2 gene transcription is induced within an hour of stimulation with mitogenic agents, peaks at $6-8 \mathrm{~h}$, and then declines later as cellular proliferation begins to wane in the cultures [6]. These findings have suggested a role for BCL2 in the control of normal cellular proliferation. We therefore explored the actions of BCL2 using the 3T3 fibroblast model for normal cellular growth regulation. Unlike the hematopoietic cell lines used for previous gene transfer studies of BCL2, quiescent 3T3 fibroblasts can survive for several days in defined media without growth factors. The murine fibroblasts thus permitted us to examine the effects of BCL2 on cellular proliferation, in the absence of confounding cell survival issues. We also followed up on a previous report showing that overexpression of p26 BCL2 caused elevated phosphatidylinositol (PI) turnover and increased synthesis of phosphatidic acid (PA) in NIH3T3 fibroblasts [7]. Because PI turnover and PA production have been linked to regulation of inositol $[1,4,5]$ triphosphate production $\left(\mathrm{IP}_{3}\right)$ (a second messenger that controls cytosolic calcium ion concentrations) and protein kinase-C (PKC) activity $[8,9]$, we therefore measured relative rates of $\mathrm{IP}_{3}$ synthesis and platelet-derived growth factor (PDGF)-induced transient elevations in cytosolic $\mathrm{Ca}^{2+}$ ions and examined PKC enzyme levels and activity in BCL2-expressing 3T3 cells. 


\section{METHODS}

Cells. The NIH3T3 cell lines R596.2 and R658.2 are stably transfected with the pSV2-BCL2 $\alpha$ expression plasmid and have been de scribed previously [10]. The RAS-transformed NIH3T3 cells R596.7 (Ref. [10]) and C74-81 (gift of A. Cuadrato) were transfected with pEJ6.6 plasmid, containing the human HA-C-RAS oncogene. The $3 \mathrm{~T} 3$ cell lines R596.1 and K596.3 were transfected with the pSV2GPT and pSV2-BCL2-AS (antisense) plasmids as described previously [10]. All cell lines were carefully maintained between 20 and $90 \%$ confluence in Dulbecco's modified Eagles' medium (DMEM) supplemented with $10 \%$ (v:v) calf serum (Hyclone). To avoid accumulation of secondary genetic events, cells were reestablished in culture from frozen stocks every $6-8$ weeks.

RNA blot analysis. Total cellular RN $\Lambda$ was isolated by a guani dine-isothiocyanate/phenol procedure [11], and the polyadenylated fraction was purified by oligodeoxythymidine-cellulose chromatography [12]. Approximately $5-\mu \mathrm{g}$ aliquotes of mRNA were size-fractionated in $0.8 \%$ agarose $/ 6 \%$ formaldehyde gels and transferred to nylon membranes. Blote were prehybridized, hybridized, and washed exactly as described [13], using either a ${ }^{32} \mathrm{P}$-cDNA for human $b c l-2, \mathrm{pB} 4$ [14], or a murine $b c l-2$ probe, pMBCL5.4 [15]. Blots were exposed to Kodak XAR film with intensifying screens at $-70^{\circ} \mathrm{C}$ for $1-10$ days. Eluting ${ }^{32} \mathrm{P}-b c l-2$ probes from membranes and rehybridizing with a ${ }^{32} \mathrm{P}$ probe for mouse beta-2-microglobulin verified nearly equivalent amounts of mRNA for all samples on blots (not shown).

Measurements of DNA synthesis. Relative levels of growth factorinduced DNA synthesis were determined in NIH3T3 cells by measuring $\left[{ }^{3} \mathrm{H}\right]$ thymidine incorporation, as described [16]. Briefly, after reaching confluence in $35-\mathrm{mm}$ dishes, monolayers of $3 \mathrm{~T} 3$ cells were washed twice with $2 \mathrm{ml}$ DMEM and cultured for $24 \mathrm{~h}$ in DMEM without serum. The media were then replaced with $1 \mathrm{ml}$ of DMEM containing 0-20 $\mathrm{ng} / \mathrm{ml}$ recombinant PDGF (Bakchem DRG030A), $0-10 \mathrm{ng} / \mathrm{ml}$ epidermal growth factor (EGF) (Boerhinger-Mannheim), $200 \mathrm{ng} / \mathrm{ml}$ recombinant insulin like growth factor-I (IGF I) (Genzyme 1211-00), or various combinations of these growth factors. After $6 \mathrm{~h}, 1 \mu \mathrm{Ci} / \mathrm{ml}\left[{ }^{3} \mathrm{H}\right]$ thymidine ( $\mathrm{sp}$ act $\sim 6 \mathrm{Ci} / \mathrm{mmol}$ ) was added to each dish and $12 \mathrm{~h}$ later cells were recovered by trypsinization and washed, and their DNA was precipitated with $10 \%$ trichloroacetic acid onto glass filters (Schleicher \& Schuell 32). Filters from duplicate cultures were then analyzed by scintillation counting and the data were averaged ( \pm standard error).

Preparation and use of BCL2-antisense oligodeoxynucleotides. The sequences of the BCL2 antisense oligodeoxynucleotides (ODNs) and control ODNs used for these studies were the same as described previously and were complementary to either the sense (TI-AS) or antisense (TI-S) strands of the human BCL2 gene in the vicinity of the translation initiate site [17]. ODNs were synthesized using an Applied Biosystems 380B DNA synthesizer and purified using HPLC reverse-phase chromatography (PRP-1 column) and C18-Sep-Pak chromatography (Waters Associates, Millipore, Inc.) as described previously [17]. Oligodeoxynucleotides eluted in $30 \%$ acetonitrile were evaporated to dryness, resuspended at 1-2 $\mathrm{m} M$ in sterile Hanks' buffered salt solution (GIBCO), and the $\mathrm{pH}$ was adjusted to 7.4 prior to storage at $-80^{\circ} \mathrm{C}$ in small aliquots. ODNs were added to cultures of 3 T3 cells containing $5 \%$ ( $v: v)$ fetal calf serum (FSC) that had been heated at $68^{\circ} \mathrm{C}$ for $1 \mathrm{~h}$ to reduce levels of active nucleases.

Measurement of $\left[{ }^{3} \mathrm{H}\right]$ inositol phosphates. Confluent cultures were labeled for $48 \mathrm{~h}$ in inositol-free DMEM with $1 \mu \mathrm{Ci} / \mathrm{ml}\left[{ }^{3} \mathrm{H}\right]$ myoinositol. The cells were then washed and placed in media containing $20 \mathrm{mM} \mathrm{LiCl}{ }_{2}$ and incubated for $10 \mathrm{~min}$ at $37^{\circ} \mathrm{C}$. Bradykinin $(1 \mu M)$ and PDGF (20 $\mathrm{ng} / \mathrm{ml}$ ) were added for $5 \mathrm{~min}$ and the reactions were terminated by addition of $1.5 \mathrm{ml}$ chloroform:methanol:hydrochloric acid (100:200:2). The cells were scraped from the dishes and the extracts were separated into two phases by addition of $0.5 \mathrm{ml}$ each, water and chloroform. The upper aqueous phases were removed, neu- tralized with $1 \mathrm{M} \mathrm{NaOH}$, and diluted with water to $3 \mathrm{ml}$. The samples were applied to 1-ml Dowex columns (AG 1-X8, formate form, 200 $400 \mathrm{mesh}) .\left[{ }^{3} \mathrm{H}\right]$ Inositol phosphates were eluted as previously described [18].

$\mathrm{Ca}^{2+}$ measurements. Subconfluent monolayers of 3T3 fibrohlasts grown on uncoated glass coverslips were deprived of serum overnight, then loaded with fura- 2 by incubating with the acetoxy-methylester of fura-2 (fura2/AM) $(15 \mu M)$ for $2 \mathrm{~h}$. Fluorescence of single fura-2loaded cells was measured using a $100 \mathrm{X}$ Nikon Fluor objective and a Nikon Diaphot epiffuorescent microscope illuminated with alternating $(100 \mathrm{~Hz}) 340$ and $380 \mathrm{~nm}$ excitation lights, and fluorescent emissions were collected at $520 \mathrm{~nm}$ ( $50 \mathrm{~nm}$ half bandwidth) by a photomultiplier tube. Output from the fluorometer was digitized, and the $380 / 340 \mathrm{~nm}$ ratio was determined and analyzed by using an AT-based analysis system (Indec, Sunnyvale, CA). Calibration of the fluorescent signal and calculation of cytosolic-free $\mathrm{Ca}^{2+}$ was performed by the method of Grynkiewicz et al. [19]. Cells were perfused with 40 $\mathrm{ng} / \mathrm{ml}$ of PDGF using micropipets.

Immunoblot detection of PKC. Rabbit antisera 201 with panreactivity for PKCs $\alpha, \beta$, and $\checkmark$ was prepared using a synthetic peptide as an immunogen that corresponded to the 12 amino acids covering the pseudosubstrate region of rat $\operatorname{PKC} \beta[20]$. The specificity of this antiserum has been demonstrated by peptide competition studies and analysis of cells that contained various PKC isoenzymes. Detergent lysates were normalized for protein content, and $100 \mu \mathrm{g} / \mathrm{lane}$ size fractionated by $7.5 \%$ SDS-PAGE prior to immunoblot analysis as described previously [20].

Measurement of phosphorylation of p68 MARCKS. Quiescent 3T3 cells in $100-\mathrm{mm}$ dishes were incubated in $2.5 \mathrm{ml} \mathrm{PO}$-free media for $2-3 \mathrm{~h}$ prior to labeling with $1.0 \mathrm{mCi}^{32} \mathrm{PO}_{4}$ for $2-3 \mathrm{~h}$. Some cultures of cells were then stimulated with $100 \mathrm{ng} / \mathrm{ml}$ tetradecanoylphorbol acetate (TPA) (Calbiochem) for 5 min prior to lysis of cells in a modified RIP $\Lambda$ buffer (containing $20 \mathrm{~m} M \mathrm{NaF}$ and $1 \mathrm{~m} M \mathrm{Na}$-ortho-vanadate) and immunoprecipitation of p68-MARCK (myristylated alanine-rich C-kinase substrate), using methods essentially as we have described previously [20]. For these experiments, detergent lysates were adjusted to $1 \mathrm{mg} / \mathrm{ml}$ (total protein) and $5 \mu \mathrm{l}$ of anti-MARCKS antiserum was added to $500 \mu \mathrm{l}$ of cellular lysates for $4 \mathrm{~h}$ at $4^{\circ} \mathrm{C}$ prior to addition of protein A Sepharose. The rabbit antiserum R435 used for these studies (gift of A. Nairn and P. Greengard) was prepared against the MARCKS protein purified from rat brain [21]. This antiserum crossreacts with the p68 MARCKS protein of murine cells [22]

\section{RESULTS AND DISCUSSION}

Influence of $B C L 2$ on growth factor requirements. We used two independently derived pSV2-BCL2-transfected 3T3 cell lines for these studies (R596.2, R658.2) and made direct comparisons with negative control (pSV2-gpt-transfected cells, R596.1) and positive control (pEJ6.6-transfected cells, R596.7 and C74.81) cell lines. Polyclonal cell lines were employed to avoid clonal bias. As reported previously [10], BCL2-expressing NIH3T3 fibroblasts retained normal morphology for months in continuous culture. These cells grew to similar densities as untransfected NIH3T3 cells and the negative control cell line R596.1. When deprived of serum, the BCL2-expression (R596.2; R658-2) and negative control-transfected (R596.1) cell lines also achieved equivalent levels of quiescence as determined by propidium iodide-based cell cycle analysis (1-2\% of cells were in $\mathrm{S}-, \mathrm{G} 2-$, or $\mathrm{M}$-phases at 2 days after serum with- 

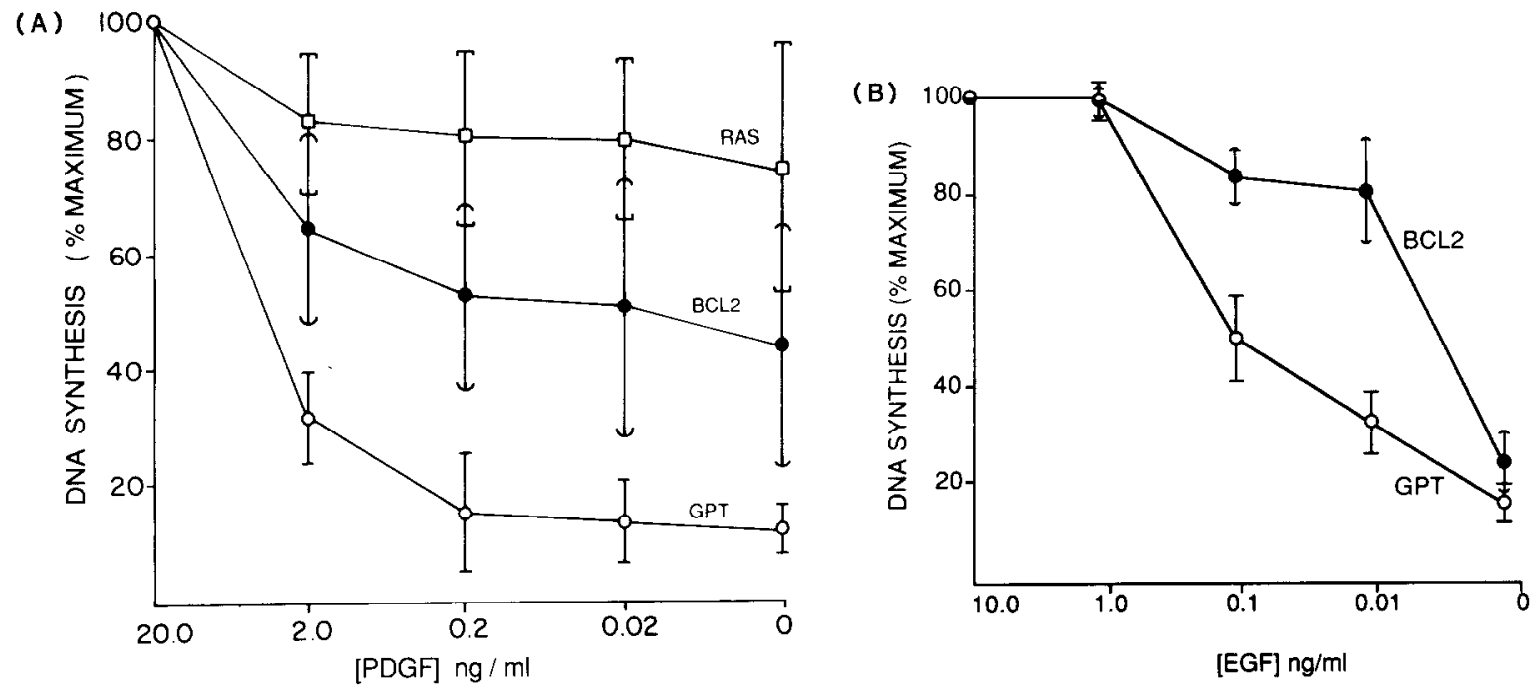

FIG. 1. BCL2 reduces growth factor requirements for optimal DNA synthesis by NIH 3T3 cells. 3T3 cells at confluence in serum-free medium were stimulated for $6 \mathrm{~h}$ with $20 \mathrm{ng} / \mathrm{ml} \mathrm{IGF-I} \mathrm{and} \mathrm{either} 0-20 \mathrm{ng} / \mathrm{ml}$ of PDGF (A) or $0-10 \mathrm{ng} / \mathrm{ml} \mathrm{EGF}(\mathrm{B}) .3 \mathrm{H}-\mathrm{TdR}(1 \mu \mathrm{Ci} / \mathrm{ml})$ was then added and $12 \mathrm{~h}$ later cellular DNA was precipitated with $10 \%$ trichloroacetic acid and collected on filters that were subjected to scintillation counting. Data are expressed as a percentage relative to maximum and represent the mean \pm standard errors of three independent experiments using the control cell line R596.1 (GPT [O]), and the R596.2, R658.2 (BCL2 [•]), and the R596.7 and C74-81 (RAS [ $\square]$ ) cell lines.

drawal). Comparable numbers of viable cells were also recovered from serum-deprived cultures of R596.1, R596.2, and R658.2 cells, indicating that BCL2 expression did not differentially influence the survival of NIH3T3 under these conditions (not shown).

In initial experiments, serum-deprived quicscent $3 \mathrm{~T} 3$ cells were supplied with optimal amounts of a progression factor (200 $\mathrm{ng} / \mathrm{ml} \mathrm{IGF}-\mathrm{I}$ ), and various concentrations of a competence factor $(0-20 \mathrm{ng} / \mathrm{ml}$ PDGF ) [23]. Relative levels of DNA synthesis $\left(\left[{ }^{3} \mathrm{H}\right]\right.$ thymidine incorporation) were then measured $18 \mathrm{~h}$ after growth factor additions. As shown in Fig. 1A, the BCL2-expressing $3 \mathrm{~T} 3$ cell lines exhibited reduced dependence on PDGF for induction of maximal DNA synthesis when compared to negative control (R596.1) transfected cells. The maximal PDGF-induced DNA synthesis in these cultures corresponded to $65-85 \%$ of cells entering the cell cycle (based on propidium iodide analysis (not shown)) for both BCL2-expressing and negative control of 3T3 cells. As expected, the RAS-transformed cell lines (used as a positive control) also displayed reduced dependence on PDGF for induction of maximal DNA synthesis (Fig. 1). When other competence factors such as EGF (Fig. 1B) and bFGF (not shown) were substituted for PDGF, similar results were obtained.

Though 3T3 cells expressing BCL2 were capable of achieving maximal DNA synthesis with reduced amounts of competence factors such as PDGF, EGF, and $\mathrm{bFGF}$, the inclusion in cultures of optimal concentrations of either IGF-I or insulin was absolutely required for maximal proliferation. Addition of $20 \mathrm{ng} / \mathrm{ml}$ PDGF alone to cultures of R596.2 and R658.2 cells re- sulted in less than a twofold increase in $\left[{ }^{3} \mathrm{H}\right]$ thymidine incorporation, whereas the combination of $20 \mathrm{ng} / \mathrm{ml}$ PDGF and $20 \mathrm{ng} / \mathrm{ml}$ IGF-I resulted in a greater than sevenfold increase in DNA synthesis (Fig. 1A and not shown). Similar results were obtained when insulin or PDGF-poor plasma was substituted for IGF-I (unpublished). Thus, overexpression of p26-BCL2 allowed these NIH3T3 cells to synthesize DNA maximally in the presence of reduced concentrations of competence-inducing growth factors (PDGF, EGF, bFGF), but not in the absence of progression factors (IGF-I, insulin). Given p26-BCL2's intramitochondrial location [2], these results imply that alterations in mitochondrial function may play an important role in the early stages of the cell cycle that render cells competent to respond to serum progression factors such as IGF-I and insulin. In this regard, it is of interest that several hormones and growth factors have been shown to influence mitochondrial metabolism [24].

To confirm the importance of BCL2 overexpression for the observed enhanced proliferative activity of pSV2-BCL2-transfected 3T3 cells, we employed BCL2 antisense ODNs. The 20-bp antisense ODN (TI-AS) used for these studies straddles the translation initiation (TI) site of human BCL 2 mRNAs and has been shown previously to result in sequence-specific reductions in BCL2 protein levels without concomitant alterations in the levels of other proteins [17]. For studies with $3 \mathrm{~T} 3$ cells, we cultured control-transfected $3 \mathrm{~T} 3$ cells (R596.1) and pSV2-BCL2-transfected cells in medium containing 5\% fetal calf serum as a source of PDGF and other growth factors. Either the antisense (TI-AS) or a 


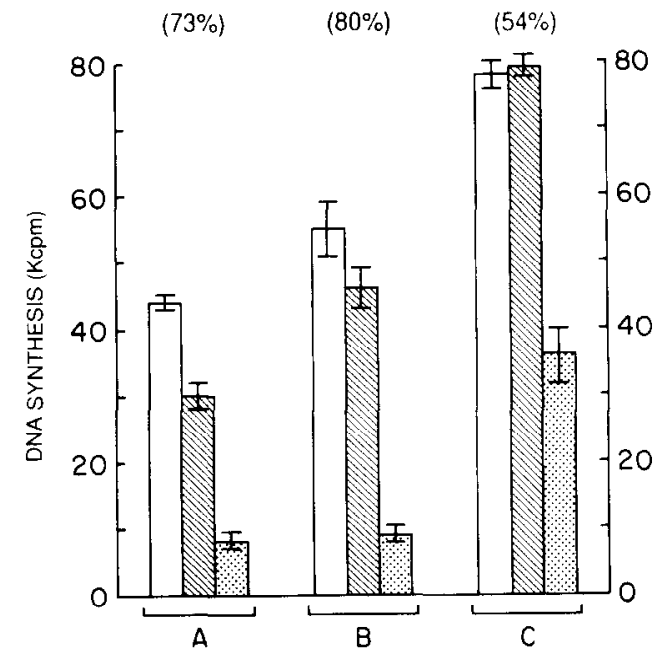

FIG. 2. Effects of BCL2 antisense oligodeoxynucleotides on 3T3 cells. The control 3T3 cell line R596.1 (A), the BCL2-antisense-expressing cell line R596.3 (B), and the BCL2-expressing cell line R596.2 (C) were seeded at low density into cultures containing $5 \%$ (vol:vol) $68^{\circ} \mathrm{C}$-treated serum. The antisense ODN (TI-AS) (dotted bars), sense ODN (TI-S) (striped bars), or diluent (open bars) was added to cultures and relative levels of DNA synthesis $(\mathrm{kcpm})$ were measured 3 days later, following a 16 -h incubation with $5 \mu \mathrm{Ci} / \mathrm{ml}$ of $\left[{ }^{3} \mathrm{H}\right]$ thymidine. Cell densities, estimated by phase-microscopy, were consistent with the measured DNA synthesis in cultures (not shown). Data represent the mean \pm standard deviation of triplicate cultures. The percentage inhibition of DNA synthesis in cultures containing the TI-AS $(100 \mu M)$ ODN was calculated relative to control cultures that received diluent and is shown in parenthesis for each cell line.

control sense ODN (TI-S) was then added to cultures, and relative levels of DNA synthesis were subsequently measured.

As shown in Fig. 2, the antisense ODN suppressed DNA synthesis in cultures of both control and pSV2BCL2-transfected 3T3 cells, whereas the control ODN had comparably little effect. Sequence-specific inhibition of cellular replication was also confirmed by cell counting for cultures treated with the antisense ODN (not shown). Importantly, the extent of inhibition of DNA synthesis by the BCL2 antisense ODN was less in the pSV2-BCL2-transfected cells (R596.2) than in the control pSV2-gpt-transfected cells (R596.1) (53\% versus $73 \%$ ), as might be expected given the higher levels of BCL2 mRNA in the R596.2 cells (Fig. 3). To further test the specificity of this antisense ODN-mediated inhibition of DNA synthesis in cultures of $3 \mathrm{~T} 3$ cells, we also made use of a cell line (R596.3) we described previously [10] that expresses a human BCL2 cDNA in antisense orientation (Fig. 3). The human BCL2 antisense transcripts produced in these cells have only $66 \%$ homology with endogenous mouse BCL2 mRNAs [15] and thus did not impair serum-induced DNA synthesis (Fig. 2B). Addition of the BCL2-sense ODN ('TI-S) to cultures of these pSV2-BCL2 antisense-expressing R596.3 cells failed to inhibit serum-induced DNA synthesis, thus ex- cluding the possibility that the mere formation of ODN-RNA heteroduplexes in cells inhibited DNA growth through nonspecific mechanisms such as induction of interferon production (Fig. 2B). The BCL2 antisense ODN (TI-AS) in contrast, impaired serum-induced DNA synthesis in these R596.3 cells to about the same extent as in cultures of control R596.1 cells (80\% versus $73 \%$ ). Moreover, experiments using an additional control ODN that had the same nucleotide composition as the TI-AS ODN but with scrambled sequence excluded the possibility that the observed reductions in DNA synthesis were attributable to cold thymidine inhibition (not shown). It is difficult, however, to make additional quantitative comparisons among the various $3 \mathrm{~T} 3$ cell lines used here for antisense experiments, because the $20^{\prime}$ mer TI-AS ODN is perfectly complementary with the human BCL2 mRNAs derived from the pSV2-BCL2 expression plasmid but has two mismatches in its $3^{\prime}$ end with endogenous mouse

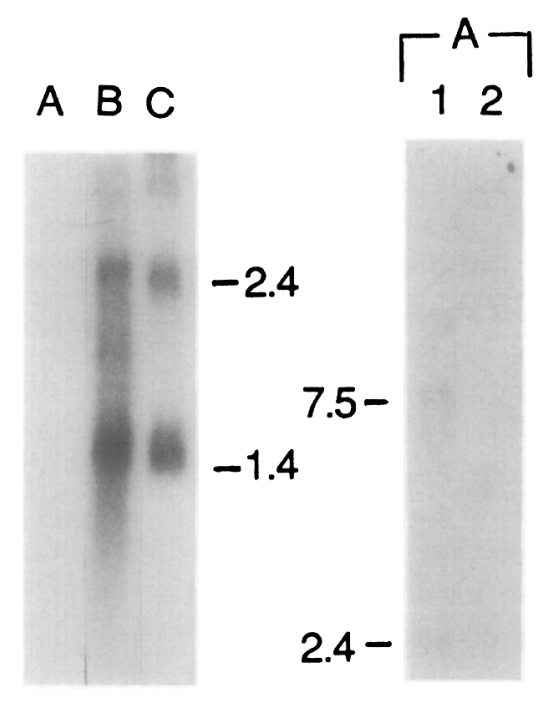

FIG. 3. RNA blot analysis of BCL2-expressing 3 T3 cells. For RNA blot analysis, polyadenylated mRNA was purified from control pSV2-gpt-transfected 3T3 cells (R596.1) and from cells stably transfected with pSV2-BCL2 expression constructs that produce either sense (R596.2) or antisense (R596.3) human BCL2 mRNAs. These pSV2-BCL2-derived transcripts include the expected 1.4-kbp BCL2/ CAT fusion mRNA and a $2.4-\mathrm{kbp}$ mRNA resulting because of an upstream cryptic transcription initiation site in this vector (see Ref. [10], and unpublished). Approximately $5 \mu \mathrm{g}$ of mRNA was subjected to RNA blot analysis, using either ${ }^{32} \mathrm{P}$-labeled hybridization probes derived from human (left) or murine (right) BCL2 cDNAs.

Shown in the left panel is the autoradiogram resulting from a 1-day exposure of a blot containing RNAs from (A) control 3T3 cells, pSV2gpt; (B) R596.3 cells, pSV2-BCL2-AS; and (C) R596.2 cells, pSV2BCL2.

The right panel represents the results of a 10-day exposure of a blot containing RNA from the control 3T3 cell line R596.1 (A) that were either proliferating (lane 1) or quiescent (lane 2) at the time of harvesting RNA. Rehybridization of these blots with a mouse $\beta 2$-microglobulin probe confirmed equivalent amounts of mRNA for each sample (not shown). 
BCL2 mRNAs [15, 17]. Nevertheless, these experiments (Fig. 2) provide supportive evidence that BCL2 contributes to the growth factor-induced cell cycle events leading to DNA synthesis in these fibroblast cell lines.

Because suppression by BCL2 antisense ODNs of DNA synthesis in cultures of the control 3T3 cell line (R596.1) suggested a role for the endogenous mouse BCL2 gene in controlling the proliferation of these fibroblasts, we also explored the regulation of BCL2 mRNA levels in these cells. As shown in Fig. 3, 3T3 fibroblasts contained very low, but detectable levels of the expected 7.5- and 2.4-kbp mouse BCL2 mRNAs when stimulated with serum but not when quiescent. When taken together with the antisense experiments, these findings imply that serum-derived growth factors can induce expression of the BCL2 proto-oncogene in these fibroblasts, and that this event is important for cell cycle events leading to DNA synthesis.

Investigations of inositol phosphates, $\mathrm{Ca}^{2+}$ and protein kinase $C$. With its mitochondrial location [2], presumably the $\mathrm{p} 26-\mathrm{BCL} 2$ protein regulates some aspect of mitochondrial function. Though mitochondria are perhaps best known for their role in oxidative-phosphorylation, these organelles may also participate in regulation of cytosolic calcium ion concentrations and other events that have been implicated in growth factor-mediated signal transduction $[25,26]$. Unloading of sequestered $\mathrm{Ca}^{2+}$ from mitochondria, for example, has been reported to occur in 3T3 fibroblasts following stimulation with PDGF [27]; thus raising the possibility that these organelles may contribute to the regulation of $\mathrm{Ca}^{2+}$-dependent enzymes such as PKC. A recent report that BCL2-transfected 3T3 fibroblasts exhibit increased PI turnover and elevated PA synthesis [7], therefore, prompted us to further investigate these signalling pathways as potential explanations for the reduced dependence on competence-inducing growth factors observed in our BCL2-expressing $3 \mathrm{~T} 3$ cell lines. PI turnover has been associated with production of $\mathrm{IP}_{3}$ (an intracellular regulator of calcium ion fluxes) through the phosphodiesteratic cleavage of phosphatidylinositol bisphosphate which yields $\mathrm{IP}_{3}$ and 1,2,-diacylglycerol (DAG). The latter, DAG, is a critical allosteric regulator of PKC activity $[8,9]$. DAG can also be converted to PA through phosphorylation by DAG kinase [28]. Since treatment of rodent fibroblasts with PA or its related phospholipids has been reported to stimulate mitogenesis and phosphatidylinositol bisphosphate hydrolysis $[29,30]$, the elevated levels of PA reported previously in BCL2-expressing $3 \mathrm{~T} 3$ cells [7] would be expected to increase $\mathrm{IP}_{3}$ and DAG production and thus result in $\mathrm{PKC}$ activation.

For these reasons, we: (1) determined relative rates of $\mathrm{IP}_{3}$ synthesis; (2) measured the effects of PDGF on cyto-

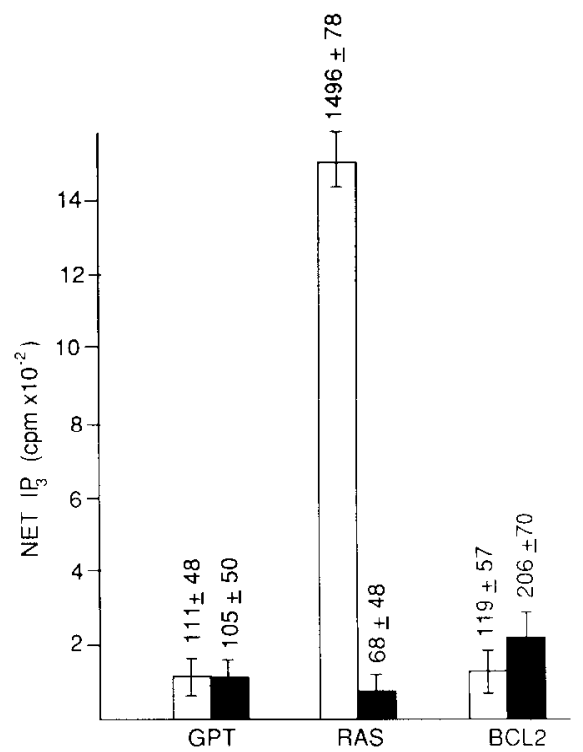

FIG. 4. Inositol triphosphate production in 3T3 cell lines. 3T3 cells expressing BCL2, RAS, or pSV2-gpt were labeled in serum free, inositol-free DMEM with $\left[{ }^{3} \mathrm{H}\right]$ myo-inositol $(1 \mu \mathrm{Ci} / \mathrm{ml})$ quiescent cells were then stimulated with Bradykinin $(1 \mu M, \square)$ or PDGF (20 $\mathrm{ng} / \mathrm{ml}$, for $5 \mathrm{~min}$ and $\left[{ }^{3} \mathrm{H}\right]$ inositol trisphosphate levels were determined. Results are expressed as means \pm SEM from four experiments.

solic $\mathrm{Ca}^{2+}$ ions; and (3) examined the status of PKC in BCL2-expressing $3 \mathrm{~T} 3$ cells. Fig. 4 shows the results of $\mathrm{IP}_{3}$ synthesis measurements for BCL2-expressing and control-transfected $3 \mathrm{~T} 3$ cells, before and after stimulation with growth factors. RAS-transformed cells were examined here as a control, since these cells have been reported to display markedly increased production of $\mathrm{IP}_{3}$ in response to bradykinin but reduced synthesis of this inositol phosphate when stimulated with PDGF $[31,32]$. As shown in Fig. 2, bradykinin induced similar rates of $\mathrm{IP}_{3}$ synthesis in BCL2-expressing and negative control (GPT) cells. Though PDGF induced slightly higher rates of $\mathrm{IP}_{3}$ synthesis in BCL2-expressing 3T3 cells, the results were not statistically significant (Fig. 4). Furthermore, no basal elevations of $\mathrm{IP}_{3}$ levels were noted in BCL2-expressing 3T3 cell lines. RAS-transformed $3 \mathrm{~T} 3$ cells, in contrast, exhibited the expected alterations in their regulation of $\mathrm{IP}_{3}$ production following stimulation with bradykinin or PDGF [31, 32]. Thus, increased $\mathrm{IP}_{3}$ production cannot account for the diminished growth factor requirements seen in our pSV2 BCL2-transfected 3T3 cell lines. Similarly, when basal and PDGF-induced elevations in cytosolic $\mathrm{Ca}^{2+}$ concentrations were examined in pSV2-BCL2-expressing 3T3 cells, no differences from control cells were noted (Fig. 5).

We next measured relative levels of immunodetectable PKC in the $3 \mathrm{~T} 3$ cell lines, as an indirect means of assessing whether p26 BCL2 overexpression leads to activation of these kinases. Tonic stimulation with 

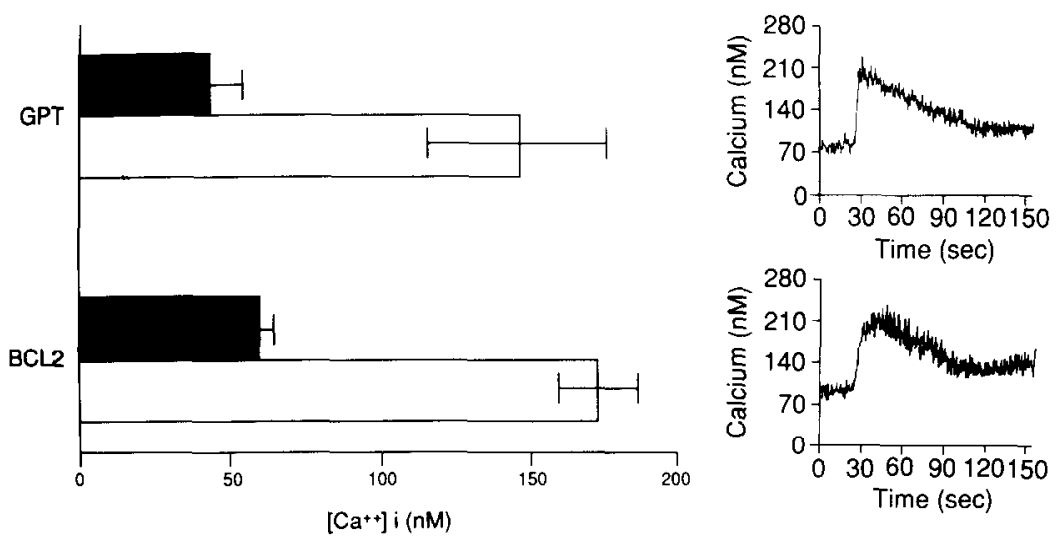

FIG. 5. Measurements of cytosolic $\mathrm{Ca}^{2+}$ concentrations in BCL2-expressing 3T3 cells. 3T3 cells loaded with $15 \mu M$ Fura $2 / \mathrm{AM}$ were stimulated with $40 \mathrm{ng} / \mathrm{ml}$ PDGF, and fluorescence of single representative cells was measured as described previously [19]. At left, mean ( \pm standard deviation) basal and peak cytosolic $\mathrm{Ca}^{2+}$ measurements are presented for control R596.1 and BCL2-expressing R596.2 cells ( $n=4$ for R596.1; $n=7$ for R596.2). No significant difference in the delay time (time from PDGF addition until maximal cytosolic $\mathrm{Ca}^{2+}$ ) was noted for the two types of cells (mean $t=4.7 \pm 3.2 \mathrm{~s}$ for R596.1; $t=6.4 \pm 2.6$ for R596.2 cells).

At right are shown representative results for R596.1 (top) and R596.2 (bottom) cells, where cytosolic $\mathrm{Ca}^{2+}$ concentrations were measured continuously over a period of $150 \mathrm{~s}$ following addition of PDGF.

DAG-like phorbol esters or by expression of particular transforming oncogenes such as RAS that induce DAG production has been shown to result in down-regulation of PKC [8, 33, 34]. As shown in Fig. 6A, immunoblot analysis of quiescent $\mathrm{BCL} 2$-expressing $3 \mathrm{~T} 3$ cell lines

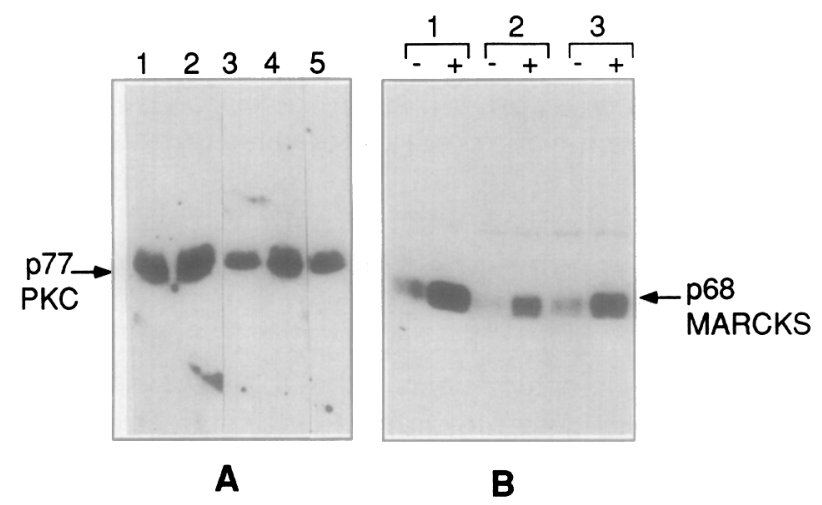

FIG. 6. Effects of BCL2 on PKC Levels and Function. (A) Detergent lysates were prepared from quiescent R596.1 (GPT) (lane 1); R596.2, R658.2 (BCL2) (lanes 2 and 4); and R596.7, C74-81 (RAS) (lanes 3 and 5) cell lines. Cell extracts were then normalized for protein content and $100 \mu \mathrm{g}$ was size-fractionated by SDS-polyacrylamide gel electrophoresis $(7.5 \%$ gels $)$ prior to transfer to nitrocellulose membranes. Blots were incubated with anti-PKC antibody 201, followed by ${ }^{125} \mathrm{I}$-labeled protein A. Loading of equal amounts of protein was confirmed by staining of a portion of filters with Ponceau S not shown). The $\mathrm{p} 77 \mathrm{PKC}$ protein bands are shown. Similar results were obtained in two other experiments. (B) Quiescent ${ }^{32} \mathrm{PO}_{4}$-labeled cells were either treated $(+)$ or not treated $(-)$ with $100 \mathrm{ng} / \mathrm{ml}$ TPA prior to lysis, normalization for protein content, and immunoprecipitation of p68-MARCKS. Proteins were size-fractionated by SDS-PAGE $(7.5 \% \mathrm{gel})$. Data are representative of three experiments. Cell lines analyzed included: (1) R596.1 (GPT); (2) R596.2 (BCL2); (3) R658.2 (BCL2).
(R596.2; R658.2) demonstrated levels of p77-PKC comparable to negative control-transfected cells (R596.1). RAS-transformed cells, in contrast, contained only about half as much total PKC, consistent with constitutive stimulation of these enzymes in cells that express a RAS oncogene [33, 34].

In vivo $\mathrm{PKC}$ activity was also assessed in BCL2-expressing 3T3 cell lines by examination of relative levels of phosphorylation of a major PKC substrate, p68 MARCKS [21, 22]. As shown in Fig. 6B, basal incorporation of ${ }^{32} \mathrm{PO}_{4}$ into immunoprecipitable p68 MARCKS was not elevated in quiescent BCL2-expressing cell lines relative to control transfected (GPT) cell lines. Moreover, a similar fold increased in ${ }^{32} \mathrm{PO}_{4}$-incorporation into p68 MARCKS was induced by the phorbol ester tetradecanoylphorbol acetate (TPA) in these cells, suggesting that $\mathrm{PKC}$ responses are not blunted in BCL2-expressing 3T3 cells, as has been reported for some oncogene-transformed 3T3 cells [34]. When taken together with the measurements of PKC levels in BCL2-expressing 3T3 cells, these findings (Fig. 6) argue against a role for PKC activation in the BCL2-mediated partial abrogation of PDGF and EGF requirements for 3T3 fibroblast proliferation.

Conclusions. In summary, the data presented here demonstrate that overexpression of the mitochondrial protein p26 BCL2 in NIH3T3 fibroblasts markedly reduces concentrations of competence-inducing growth factors necessary for achieving maximal levels of DNA synthesis. Previous investigations of the regulation of BCL2 gene expression have demonstrated a correlation between cellular proliferation and levels of BCL2 mRNAs, suggesting that this proto-oncogene may participate in the control of normal cellular growth $[6,35]$. 
Our findings in BCL2-transfected 3T3 fibroblasts provide further strong support that BCL2 enhances cellular growth, in addition to its effects on cellular survival. Moreover, since p26 BCL2 is found exclusively in mitochondria $[2]$, our data imply that specific unknown alterations in mitochondrial function can partially supplant the need for competence-inducing growth factors in stimulating cellular proliferation.

We thank Angus Nairn, Paul Wang, and Paul Greengard for antiMARCKS antibody; Antonnio Cuadrato for C74-81 cells; Zhou Zhou Gai for advice on proliferation assays; Ken Ray for artwork; and Shirley Johnston for manuscript preparation. This work was supported by grants fron the Leukemia Society of America (special fellowship to J.R.), The Dermatology Foundation (H.T.), NIH Fogerty International Center (FO5DW04545 to G.B.), Lucille P. Marke Foundation, American Cancer Society $(\mathrm{CH}-460)$ and NIH grants CA49576, AR39691, and DK-15120.

\section{REFERENCES}

1. Croce, C. M., Erikson, J., Tsujimoto, Y., and Nowell, P. (1987) in Advances in Viral Oncology (Klein, G., Ed.), Vol. 7, pp. 35-51, Raven Press, New York.

2. Hockenbery, D., Nunez, G., Milliman, C., Schreiber, R., and Korsmeyer, S. (1990) Nature 348, 334-336.

3. Vaux, D., Cory, S., and Adams, J. (1988) Nature 335, 440-442.

4. Nunez, G., I.ondon, I.., Hockenberry, D., Alexander, M., McKearn, J., and Korsmeyer, S. (1990) J. Immunol. 144, 3602 3610 .

5. Reed, J., Cuddy, M., Haldar, S., Croce, C., Nowell, P., Makover, D., and Bradley, K. (1990) Proc. Natl. Acad. Sci. USA 87, 36603664 .

6. Reed, J., Tsujimoto, Y., Alpers, J., Croce, C., and Nowell, P. (1987) Science 236, 1295-1299.

7. Haldar, S., Reed, J., Beatty, C., and Croce, C. (1990) Cancer Res. 50, 7399-7401.

8. Berridge, M. J., and Irvine, R. F. (1989) Nature 34 1, 197-205.

9. Nishizuka, Y. (1986) Science 233, 305-312.

10. Reed, J., Cuddy, M., Slabiak, T., Croce, C., and Nowell, P. (1988) Nature 336, 259-261.

11. Chomczynski, P., and Sacchi, N. (1987) Anal Biochem. 163, 156-159.

12. Aviv, H., and Leder, P. (1972) Proc. Natl. Acad. Sci. USA 69, 1408-1412.

Received January 17, 1991

Revised version received March 25, 1991
13. Reed, J. C., Sabath, D., Hoover, R. G., and Prystowsky, M. B. (1985) Mol. Cell Biol. 5, 3361-3366.

14. Tsujimoto, Y., and Croce, C. (1986) Proc. Natl. Acad. Sci. USA 83, 5214-5218.

15. Negrini, M., Silini, E., Kozak, C., Tsujimoto, Y., and Croce, C. M. (1987) Cell 49, 455-463.

16. Keledar, A., and Cole, M. (1987) Mol. Cell Biol. 7, 3899-3907.

17. Reed, J., Stein, C., Haldar, S., Croce, C., Subsing̀e, C., Yum, S., and Cohen, J. (1990) Cancer Res. 50, 6565.

18. Berridge, M., Dawson, R., Downes, C., Heslop, J., and Irvine, R. (1983) Biochem. J. 212, 773-782.

19. Grynkiewicz, G., Poenic, M., and Tsien, R. Y. (1985) J. Biol. Chem. 260, 3440-3450.

20. Reed, J., Yum, S., Cuddy, M., Turner, T., and Rapp, U. (1991) Cell Growth Differ. 2, 675-683.

21. Wang, J., Walaas, S., Sihra, T., Aderem, A., and Greengard, P. (1989) Proc. Natl. Acad. Sci. USA 86, 2253-2256.

22. Aderem, A., Albert, K., Keurm, M., Wang, J., Greengard, P., Cohen, Z. (1988) Nature 332, 362-364.

23. Stiles, C., Capone, G., Scher, C., Antoniades, J., Wyk, V., and Pledger, W. (1979) Proc. Natl. Acad. Sci. USA 76. 1279-1283.

24. Denton, R., and McCormack, J. (1985) Am. J. Physiol. 249, E543-E554.

25. Rottenberg, H., and Marbach, M. (1990) Biochem. Biophys. Acta 1016, 87-98.

26. Ota, A. (1990) Med. Hypothoses 32, 37-38.

27. Frantz, C. (1985) Exp. Cell. Res. 158, 287-300.

28. Majarus, P., Connolly, T., Deckmyn, H., Ross, 'T'., Bross, 'T., Ishii, H., Bansal, V., and Wilson, D. (1986) Science 234, 1519 1526.

29. Moolenaar, W., Kruijer, W., Tilly, B., Verlaar, I., Bierman, A., and de Laat, S. (1986) Nature 323, 171-173.

30. van Corver, E., Groenink, A., Jalink, K., Eichholtz, T., and Moolenaar, W. (1989) Cell 59, 45-54.

31. Alanzo, T., Srivastava, S., and Santos, E. (1990) Mol. Cell. Biol. 10, 3117-3124.

32. Benjamin, C., Tarpley, W., and Gorman, R. (1987) Biochem. Biophys. Res. Commun. 145, 1254-1259.

33. Chiaugi, V., Bruni, P., Pasquali, F., Magnelli, L., Basi, G., Rug giero, M., and Franararo, M. (1989) Biochem. Biophys. Res. Commun. 164, 816-823.

34. Wolfman, A., and Macara, I. (1987) Nature 325, 359-361.

35. Graninger, W., Seto, M., Boutain, B., Goldman, P., and Korsmeyer, S. (1987) J. Clin. Invest. 80, 1512-1515. 